\title{
Impact of grazing from capelin (Mallotus villosus) on zooplankton: a case study in the northern Barents Sea in August 1985
}

\author{
ARNE HASSEL, HEIN RUNE SKJOLDAL, HARALD GJØSÆTER, HARALD LOENG and LENA OMLI
}

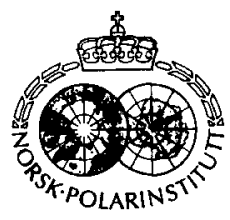

Hassel, A., Skjoldal, H. R., Gjøsæter. H., Loeng, H. \& Omli. L. 1991: Impact of grazing from capelin (Mallotus villosus) on zooplankton: a case study in the northern Barents Sea in August 1985. Pp. 371-388 in Sakshaug. E., Hopkins, C. C. E. \& Øritsland, N. A. (eds.): Proceedings of the Pro Mare Symposium on Polar Marine Ecology, Trondheim, 12-16 May 1990. Polar Research 10(2).

The distribution of capelin was mapped in the area east of Hopen. Zooplankton was sampled with Juday net and $1 \mathrm{~m}^{2}$ MOCNESS sampler, and analysed with respect to hydrography and capelin abundance. The capelin "front" coincided more or less with the physical Polar Front, and this complicated the interpretation of the results. Strong indications for a grazing impact by capelin on zooplankton were nevertheless obtained. The zooplankton biomass was significantly lower in the area with high abundance of capelin than in the area with no capelin. This effect was due to a lower biomass of relatively large zooplankton ( $>1 \mathrm{~mm}$ size fraction) and seen most clearly in data obtained with the MOCNESS. The biomass of zooplankton in the upper $100 \mathrm{~m}$ was very low where capelin was present, suggesting rapid depletion of the major prey items. The biomass $\left(\mathrm{m}^{-2}\right)$ of capelin in the capelin front area was about three times higher than the biomass of zooplankton in areas without capelin. The capelin front would therefore have the potential to graze down the available prey in 3-4 days. Light seems to be an important factor for the predation impact by capelin, resulting in strong interactions between capelin predation and zooplankton vertical distribution.

Arne Hassel. Hein Rune Skjoldal. Harald Gjøsater. Harald Loeng and Lena Omli, Institute of Marine Research, P.O. Box 1870 Nordnes, N-5024 Bergen, Norway.

\section{Introduction}

The Barents Sea ecosystem is characterised by inflow of relatively warm Atlantic Water in the southwestern area. The Atlantic Water is separated from the cold Arctic Water in north by a Polar Front, which is topographically determined and sharp in the western part of the Barents Sea while being more diffuse and variable in the eastern part (Loeng 1989, 1991 this volume). There is large seasonal and interannual variability in the ice cover, with from $1 / 3$ to $2 / 3$ of the area of the Barents Sea covered by ice during winter (Vinje 1983; Loeng 1989).

The melting of ice initiates an ice edge phytoplankton bloom (Rey \& Loeng 1985; Rey et al. 1987a, b; Skjoldal et al. 1987) which can be envisaged as a band of production sweeping northwards as the ice recedes. The ice edge bloom is utilised for reproduction and development of Arctic herbivorous zooplankton dominated by the copepod Calanus glacialis which has a twoyear life cycle (Tande et al. 1985; Hassel 1986). The dominant herbivores in the Atlantic Water south of the Polar Front are C. finmarchicus, which has a one-year life cycle, and several species of krill (Hassel 1986; Loeng 1989; Skjoldal \& Rey 1989; Dalpadado \& Skjoldal 1991 this volume).

The Capelin (Mallotus villosus Müller) is a small salmonid fish which plays an important role in the Barents Sea ecosystem as a plankton feeder (Skjoldal \& Rey 1989; Hamre 1990). It matures at an age of 3-5 years upon reaching a size of about $14 \mathrm{~cm}$ (Forberg \& Tjelmeland 1985), and migrates to the coasts of northern Norway and Murman to spawn in late winter. The spent individuals experience massive mortality following spawning. The immature part of the population overwinter in the central Barents Sea, from where they undertake a large-scale feeding migration to the northern Barents Sea during summer and autumn (Ozhigin \& Ushakov 1984; Dommasnes \& Røttingen 1984; Hamre 1990). This feeding migration can be viewed as an ecological adaptation whereby the capelin follow, with a time lag, the receding ice edge, exploiting the secondary production based on the ice edge phytoplankton bloom (Sakshaug \& Skjoldal 1989).

The feeding conditions and growth of capelin have been investigated by the Institute of Marine Research since 1979. From 1984 these inves- 
tigations have been part of the Pro Mare programme. A conceptual model of the seasonal development of the Barents Sea ecosystem, based on the receding ice edge, an ice edge phytoplankton bloom, zooplankton development. and capelin feeding migration, has been central for coordination of much of the research activity in Pro Mare (Loeng \& Hassel 1986; Rey et al. 1987b; Sakshaug \& Skjoldal 1989). This model emphasises the passive role of capelin at the receiver end of the food chain, harvesting the secondary production as it trails the receding ice edge. It is expected, however, that capelin also plays an important active role in the ecosystem through feedback effects on the plankton populations. A pattern of higher zooplankton biomass in front of rather than behind a migrating "front" of capelin has been observed and interpreted to be the result of predation (Hassel 1986).
In an attempt to obtain more direct evidence for the predation impact by capelin, a detailed investigation was carried out in August 1985. The northern boundary of the capelin distribution is typically sharp, with high abundance of capelin often found as a narrow band in a characteristic "capelin front". The location of the capelin front was mapped in the area east of Hopen, and physical and biological conditions were surveyed in front of and behind the capelin front (Fig. 1). The capelin front area was revisited after about one week in order to assess possible changes caused by the migrating capelin. At the time of investigation, however, the capelin front more or less coincided with the physical Polar Front. This was an unfortunate coincidence which has made it difficult to provide firm evidence for the predation impact by capelin on the zooplankton populations.

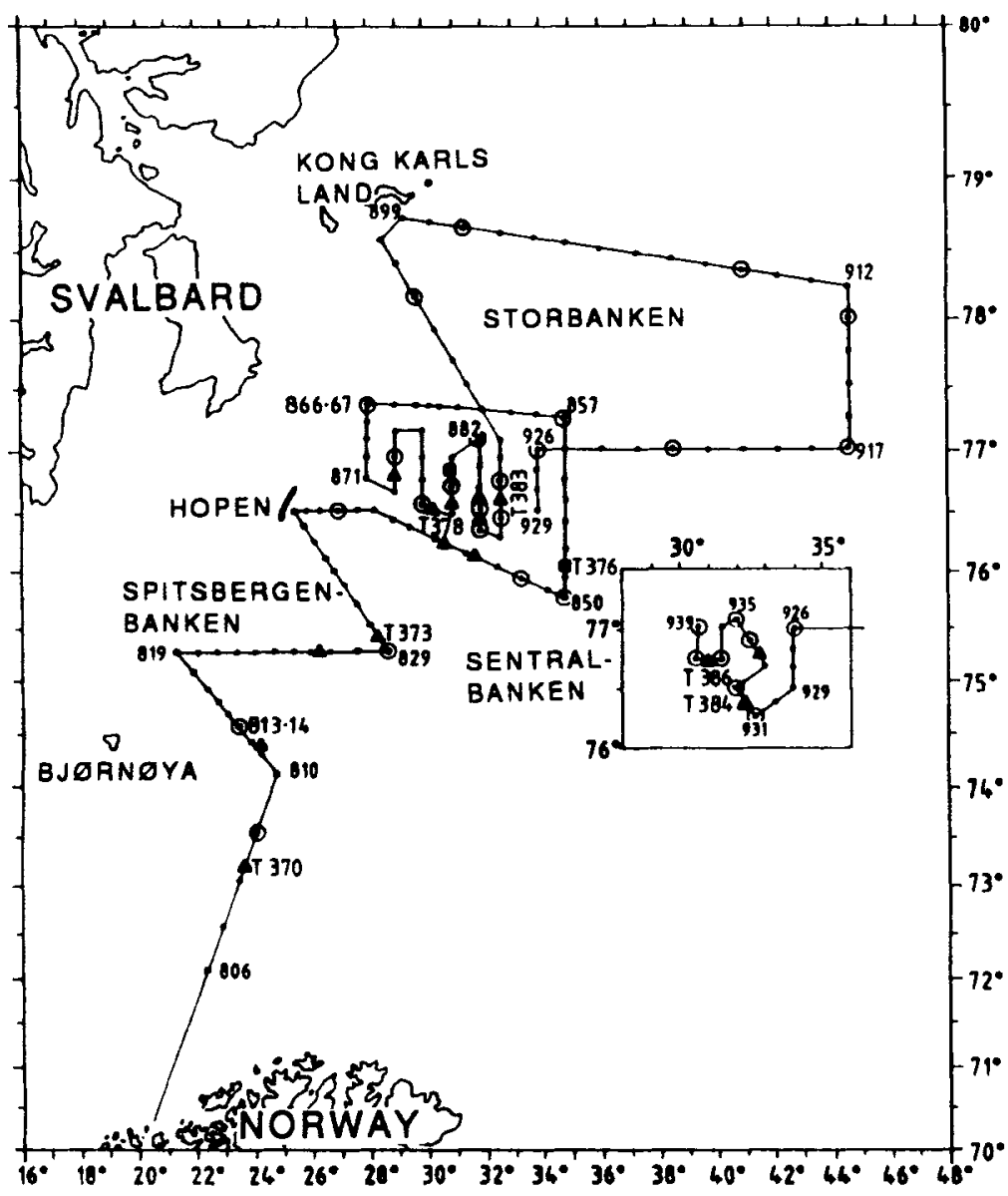

Fig. 1. Survey routcs for R/V G.O SARS in the period 1-19 August 1985. CTD- and Juday-net stations are indicated with dots, MOCNESS hauls with open circles, pelagic trawl hauls with triangles, and bottom trawl hauls with squares. 


\section{Material and methods}

The investigation was carried out during a cruise with $\mathrm{R} / \mathrm{V}$ G. O. SARS from 29 July to 19 August 1985. The cruise track and sampling stations are shown in Fig. 1. A total of 134 CTD stations were taken during the cruise. The main area of investigation was located east of Hopen between $75^{\circ} 45^{\prime}$ and $77^{\circ} 30^{\prime} \mathrm{N}$ and between $28^{\circ}$ and $35^{\circ} \mathrm{E}$. We were assisted in the initial localisation of the capelin front and mapping of the physical conditions by $R / V$ HÅKON MOSBY from the University of Bergen.

Zooplankton was sampled with a $36 \mathrm{~cm}$ diameter Juday net and a $1 \mathrm{~m}^{2}$ MOCNESS plankton trawl. The Juday net $(180 \mu \mathrm{m})$ was hauled vertically from near bottom to the surface at a total of 128 stations. Vertical profiles of zooplankton distribution were obtained at 30 stations with the MOCNESS sampler (Fig. 1). The MOCNESS was equipped with 9 nets $(333 \mu \mathrm{m})$ that were electronically released from the ship (Wiebe et al. 1976; Wiebe et al. 1985). The MOCNESS was towed horizontally at 8 selected depths or obliquely in 8 depth intervals from a distance of $20-30 \mathrm{~m}$ from the bottom to the surface (the 9 th net was not used). Mean biomass per $\mathrm{m}^{3}$ was calculated as the weighted average biomass per $\mathrm{m}^{3}$ for the depth layers in a profile. The biomass per $\mathrm{m}^{2}$ was obtained by multiplying the mean biomass per $\mathrm{m}^{3}$ with the water depth at the station.

All zooplankton samples were divided with a Motoda splitter (Motoda 1959) into two aliquots for determination of dry weight biomass and species composition, respectively. The biomass subsamples were sieved successively through $1000 \mu \mathrm{m}$ and $250 \mu \mathrm{m}$ screens, rinsed briefly with fresh water and frozen in pre-weighed Al-trays. These samples were later dried $\left(80^{\circ} \mathrm{C}\right)$ and combusted $\left(450^{\circ} \mathrm{C}\right)$ to obtain dry weight $(\mathrm{dw})$ and ashfree dry weight (afdw). All specimens of medusae and ctenophores from the MOCNESS samples were removed prior to the subsampling procedure, identified to species, and sized by volume or length.

\section{Results}

\section{Hydrography and water masses}

The circulation pattern in the area east of Hopen is characterised by Atlantic Water that divides into a branch that flows northwards submerged under the Arctic Water west of Storbanken and a branch that flows eastwards between Storbanken and Sentralbanken. Cold Arctic Water flows southwestwards along the eastern slope of Spitsbergenbanken (Loeng 1989; 1991). The Polar Front closely follows the bottom topography in this area.

Apart from the southern stations in Atlantic Water, the investigation area had been influenced by ice cover, resulting in a surface layer of meltwater with a well-defined pyknocline at $20-30 \mathrm{~m}$ depth. Based on water mass characteristics, we have, according to Loeng (1991), classified the sampling stations into the following categories:

- Arctic Water. Salinity between 34.3 and $34.8 \%$ o and temperature below $0^{\circ} \mathrm{C}$.

- Atlantic Water. Salinity above $35.0 \%$ and temperature above $3^{\circ} \mathrm{C}$.

- Polar Front Water. Salinity between 34.8 and $35.0 \%$ and temperature between -0.5 and $2^{\circ} \mathrm{C}$. A mixture of Arctic and Atlantic water, locally formed in a transition zone.

- Spitsbergenbanken water, with salinity below $34.4 \%$ and temperature between $1-3^{\circ} \mathrm{C}$.

In addition we have defined:

- Arctic/Atlantic water. Arctic Water overlaying Atlantic Water, which is found near the bottom.

— "Old" Atlantic Water. Salinity above $34.9 \%$ and temperature $0-2^{\circ} \mathrm{C}$. Atlantic Water in origin, with a long residence time in the area.

Examples of temperature and salinity profiles from the different water-mass categories are shown in Fig. 2A-F. The horizontal distribution of temperature at $50 \mathrm{~m}$ showed marked gradients (Fig. 3A). The $0^{\circ} \mathrm{C}$ isoline marks the approximate position of the Polar Front. The distribution of the water-mass categories at the time of this study is shown in Fig. 3B. The Polar Front water mass separated the Arctic and Atlantic water masses, with "old" Atlantic Water intermediate in position over the deeper areas of the Hopen Deep. The Arctic/Atlantic water mass was found where Atlantic Water intrudes under the Arctic Water at about $30-32^{\circ} \mathrm{E}$. Further details of the hydrographic conditions during the survey are presented by Loeng et al. (1986).

\section{Capelin distribution}

The distribution of capelin revealed maximum 

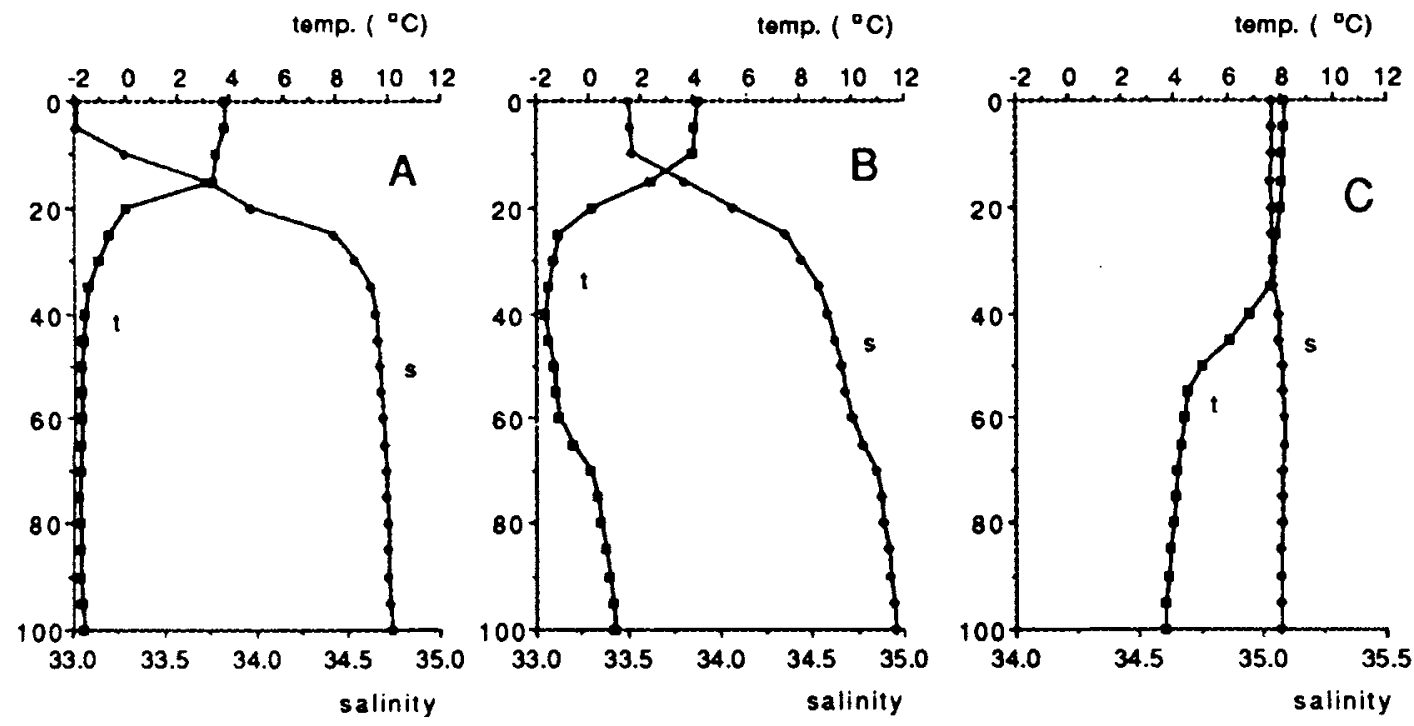

temp. $\left({ }^{\circ} \mathrm{C}\right)$

tomp. $(\circ \mathrm{C})$
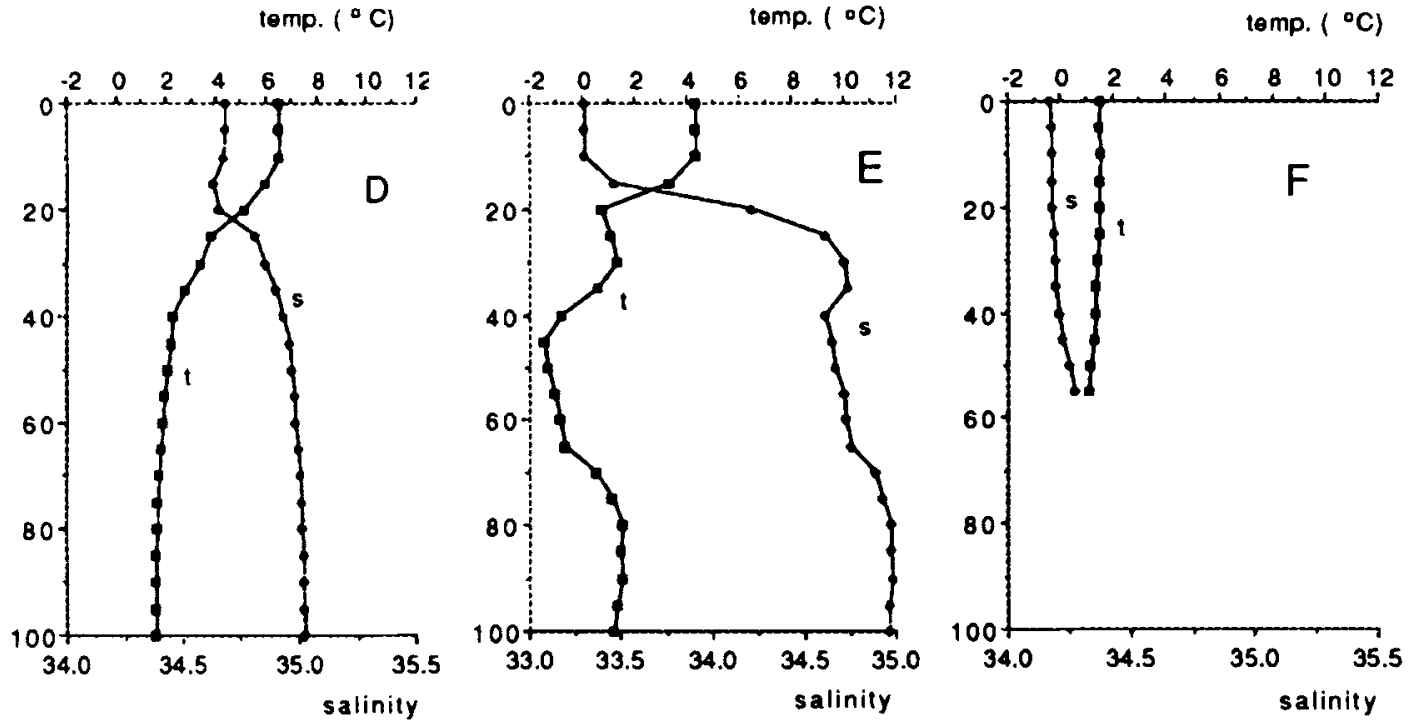

Fig. 2. Examples of vertical profiles of temperature and salinity. $\mathrm{A}=$ Arctic Water (Station 913). B = Arctic/Atlantic (Station 89()$) . C=$ Atlantic (Station 8(99). $D=$ Old Atlantic (Station 829). $E=$ Polar Front (Station 873) $F=$ Spitsbergenbanken (Station $838)$.

abundance in an area just south of the Polar Front between $76^{\circ}$ and $76^{\circ} 30^{\prime} \mathrm{N}$ and between $30^{\circ}$ and $36^{\circ} \mathrm{E}$ (Fig. 3D). The zero isoline of capelin ran almost parallel to the Polar Front, especially along the eastern slope of Spitsbergenbanken. South of Storbanken. capelin were found to have penetrated just into Arctic Water. The position of the capelin front did not change much during the last week of the investigation when a second survey of the central area was conducted (Fig. 1). The isoline for echo integrator value 100 had moved 15-20 n.miles to the north, whereas the zero isoline had receded slightly (Fig. 3C). It appears that the timing of our cruise coincided with the time when the capelin were about to cross the Polar Front. Echo registrations obtained 

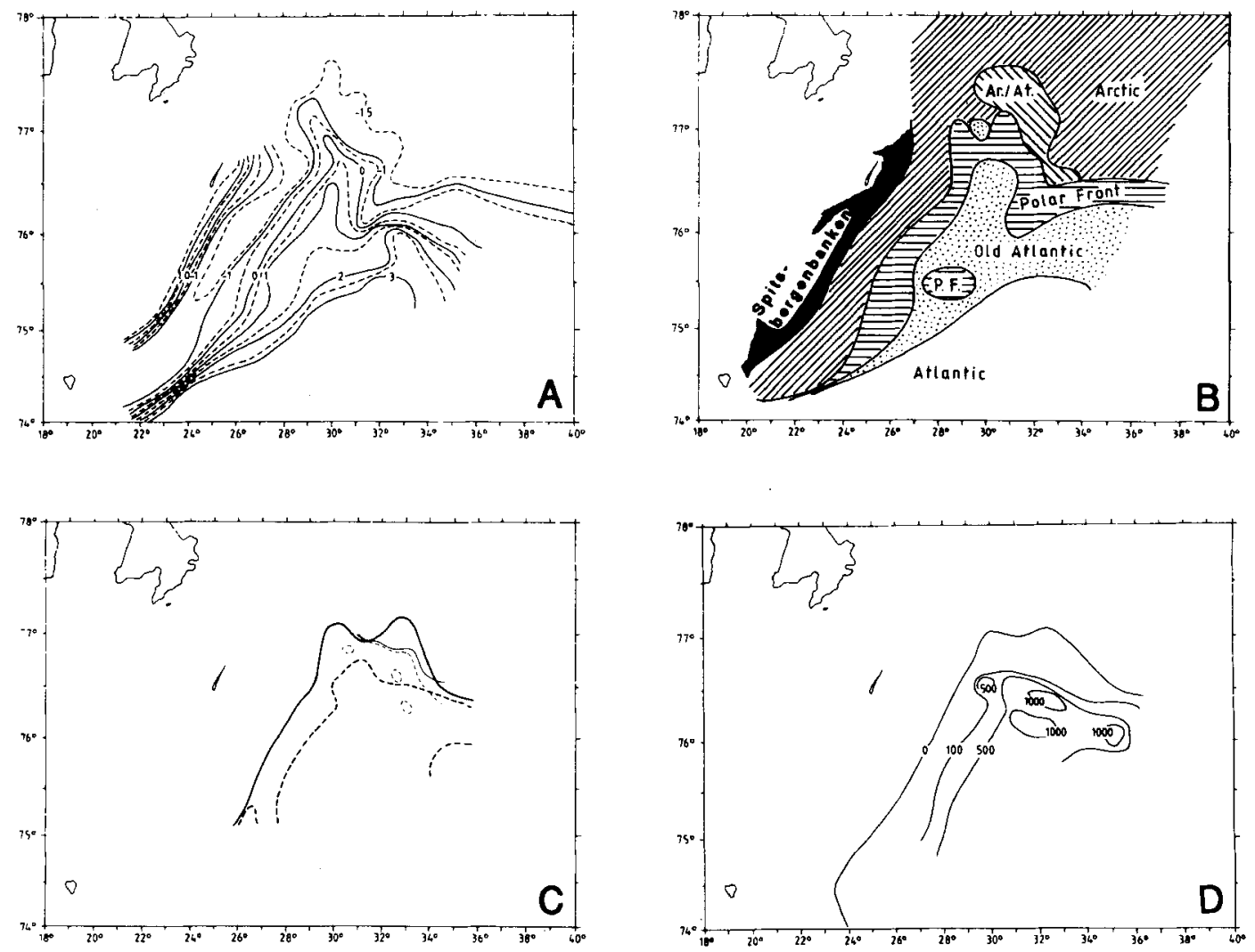

Fig. 3. Physical and biological properties of the central area of investigation. $\mathrm{A}=$ temperatures in $50 \mathrm{~m}$ depth. $\mathrm{B}=\mathrm{schematic}$ distribution of the water types observed during the cruise. $\mathrm{C}=$ position of the capelin front during the first (fat lines) and second (thin lines) coverage. Solid isolines indicate echo integrator values $=0$, and broken isolines indicate values $=100 . \mathrm{D}=\mathrm{distribution}$ of capelin echo integrator values.

one month later during the annual autumn survey of capelin revealed that the capelin concentrations had migrated further north to beyond $78^{\circ} \mathrm{N}$, south of Kong Karls Land (Anon 1985).

Table 1 summarises the mean numerical abundances, condition factors and individual weights of 2,3 and 4 year-old capelin in the various watermass categories. The 3 year-old individuals were the dominant age group, with the largest relative dominance in the Arctic, Arctic/Atlantic and "old" Atlantic Water masses. The lowest numerical abundance was found in Atlantic Water where

Table 1. Mean weight, condition factor and number of individuals of 2,3, and 4-year classes of capelin from different water masses.

\begin{tabular}{lllllllrrr}
\hline Water mass & $\begin{array}{l}\text { Weight (g) } \\
2 \mathrm{yrs}\end{array}$ & $\begin{array}{l}\text { Weight }(\mathrm{g}) \\
3 \mathrm{yrs}\end{array}$ & $\begin{array}{l}\text { Weight (g) } \\
4 \mathrm{yrs}\end{array}$ & $\begin{array}{l}\text { Cond. } \\
2 \mathrm{yrs}\end{array}$ & $\begin{array}{l}\text { Cond. } \\
3 \mathrm{yrs}\end{array}$ & $\begin{array}{l}\text { Cond. } \\
4 \mathrm{yrs}\end{array}$ & $\begin{array}{r}\text { Nos. } \\
2 \mathrm{yrs}\end{array}$ & $\begin{array}{l}\text { Nos. } \\
3 \mathrm{yrs}\end{array}$ & $\begin{array}{l}\text { Nos. } \\
4 \mathrm{yrs}\end{array}$ \\
\hline Arctic & 11.43 & 14.24 & 16.83 & 4.54 & 4.54 & 4.75 & 7 & 84 & 6 \\
Arctic/Atl. & 8.20 & 9.78 & 10.86 & 4.08 & 4.34 & 4.45 & 20 & 55 & 7 \\
Atlantic & 5.37 & 6.57 & 8.00 & 4.17 & 4.44 & 4.35 & 38 & 7 & 1 \\
Old Atlantic & 7.29 & 11.24 & 12.81 & 4.03 & 4.42 & 4.43 & 35 & 173 & 21 \\
Polar Front & 6.44 & 11.58 & 13.90 & 4.21 & 4.41 & 4.34 & 201 & 401 & 41 \\
Spitsbergenbanken & - & - & - & - & - & - & - & - & - \\
\hline
\end{tabular}


2 year-old individuals dominated. The mean fish weight and condition factor were highest in the Arctic water mass for all age groups. The individual fish weight was lowest in the Atlantic Water where the weights were only about half of the weights in Arctic Water.

\section{Zooplankton biomass}

The horizontal distributions of zooplankton biomass (expressed as afdw) in the size fractions $<1 \mathrm{~mm}$ and $>1 \mathrm{~mm}$ are shown in Fig. 4 . Most of the biomass was in the $>1 \mathrm{~mm}$ fraction for both Juday and MOCNESS samples. The total biomass (the two size fractions combined) ranged from 0.6 to $14.5 \mathrm{~g}$ afdw m $\mathrm{m}^{-2}$ with a mean of $4.6 \mathrm{~g} \mathrm{~m}^{-2}$ (standard deviation (SD) 2.4) for the Juday samples, and from 0.5 to $12.7 \mathrm{~g} \mathrm{~m}^{-2}$ with a mean of $4.4 \mathrm{~g} \mathrm{~m}^{-2}$ (SD 3.0) for the MOCNESS samples.
There was no clear-cut pattern in the distribution of biomass. The Juday samples tended to show the highest values in the eastern part of the area for the smallest size fraction and scattered in the northern part and along the slope of Spitsbergenbanken for the $>1 \mathrm{~mm}$ fraction (Fig. 4 A. B). The MOCNESS samples showed the lowest values for the $>1 \mathrm{~mm}$ fraction in the central part of the investigated area (Fig. 4C), where the densest concentrations of capelin were found (Fig. 3D).

Zooplankton biomass data grouped according to water mass categories are summarised in Table 2 , with levels of significance for pairwise comparisons of total biomass given in Table 3. For the Juday samples, the lowest biomass values occurred in Spitsbergenbanken and Atlantic water masses. The highest total biomass occurred in "old" Atlantic Water. The Spitsbergenbanken
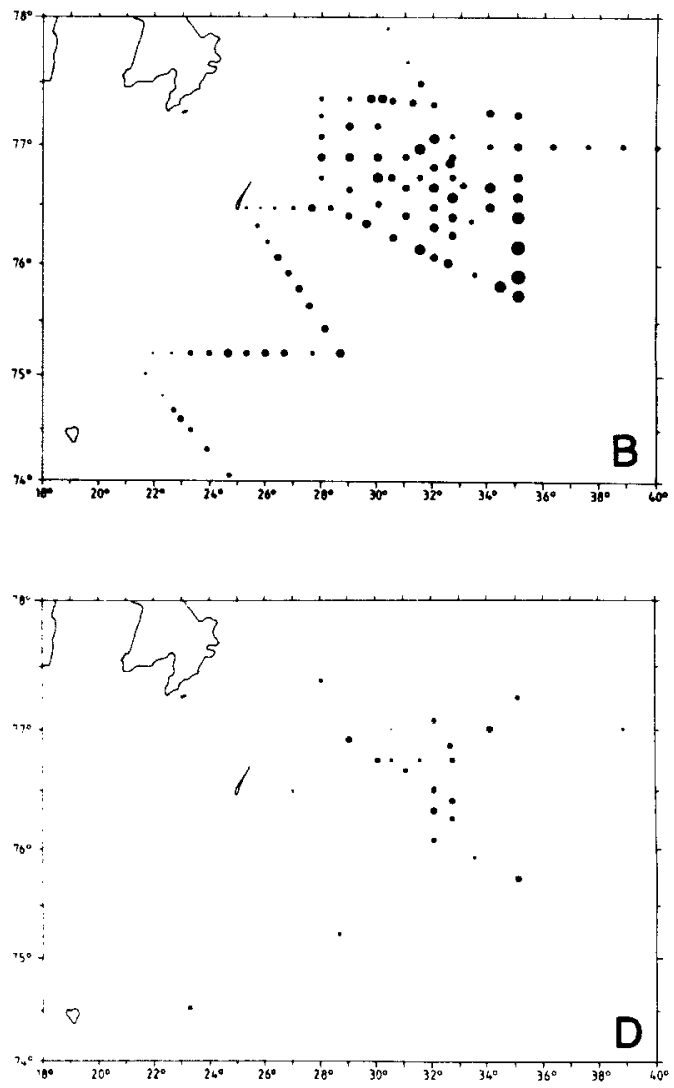

Fig. 4. Relative values of zooplankton biomass (ash frec dry weight, in $\mathrm{g} \mathrm{m}^{-2}$ ) in the central area of investigation. The magnitude of biomass is proportional to the area of the circles. $A-B=$ data from Juday net. $C-D=$ data from MOCNESS. A. C $=>1 \mathrm{~mm}$ size fraction: $B, D=<1 \mathrm{~mm}$ size fraction. 

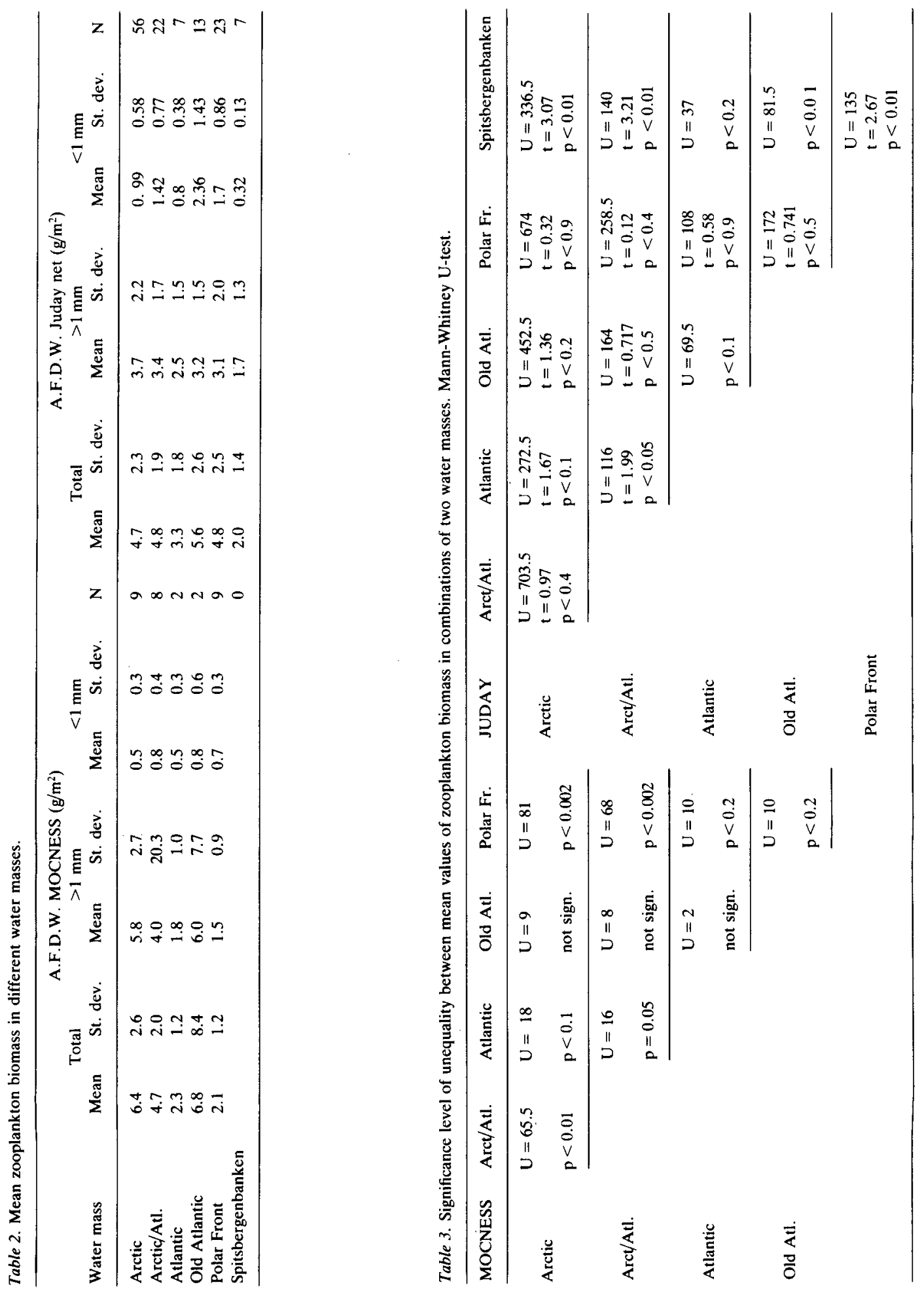
Table 4. Mean zooplankton biomass from areas with different capelin abundance

\begin{tabular}{|c|c|c|c|c|c|c|c|c|c|c|c|c|c|c|}
\hline \multirow[b]{3}{*}{ Integr. value } & \multicolumn{6}{|c|}{ A.F.D.W. MOCNESS $\left(\mathrm{g} / \mathrm{m}^{2}\right)$} & \multicolumn{8}{|c|}{ A.F.D.W. Juday net $\left(g / \mathrm{m}^{2}\right)$} \\
\hline & \multicolumn{2}{|c|}{ Total } & \multicolumn{2}{|c|}{$>1 \mathrm{~mm}$} & \multicolumn{2}{|c|}{$<1 \mathrm{~mm}$} & \multirow[b]{2}{*}{$\mathbf{N}$} & \multicolumn{2}{|c|}{ Total } & \multicolumn{2}{|c|}{$>1 \mathrm{~mm}$} & \multicolumn{2}{|c|}{$<1 \mathrm{~mm}$} & \multirow[b]{2}{*}{$\mathrm{N}$} \\
\hline & Mean & St. dev. & Mean & St. dev. & Mean & St. dev. & & Mean & St. dev. & Mean & St. dev. & Mean & St. dev. & \\
\hline 0 & 5.74 & 2.52 & 5.14 & 2.66 & 0.59 & 0.34 & 15 & 4.57 & 2.29 & 3.53 & 2.02 & 1.04 & 0.72 & 90 \\
\hline $1-100$ & 5.34 & 5.09 & 4.44 & 4.81 & 0.86 & 0.31 & 4 & 5.46 & 2.47 & 3.42 & 1.66 & 2.04 & 1.18 & 18 \\
\hline$>100$ & 2.27 & 1.47 & 1.61 & 1.19 & 0.66 & 0.34 & 11 & 3.99 & 2.49 & 2.29 & 1.73 & 1.7 & 0.94 & 20 \\
\hline
\end{tabular}

water had significantly $(\mathrm{p}<0.05)$ lower total biomass than all other water masses except the Atlantic, and the Atlantic water mass had significantly lower biomass than the Arctic/Atlantic water masses (Table 3). The MOCNESS data also showed low biomass in the Atlantic Water and high biomass in the "old" Atlantic Water (Table 2). In contrast to the Juday samples, however, the MOCNESS data showed low biomass values for the Polar Front Water that had significantly lower biomass than the Arctic and Arctic/Atlantic water masses (Table 3).
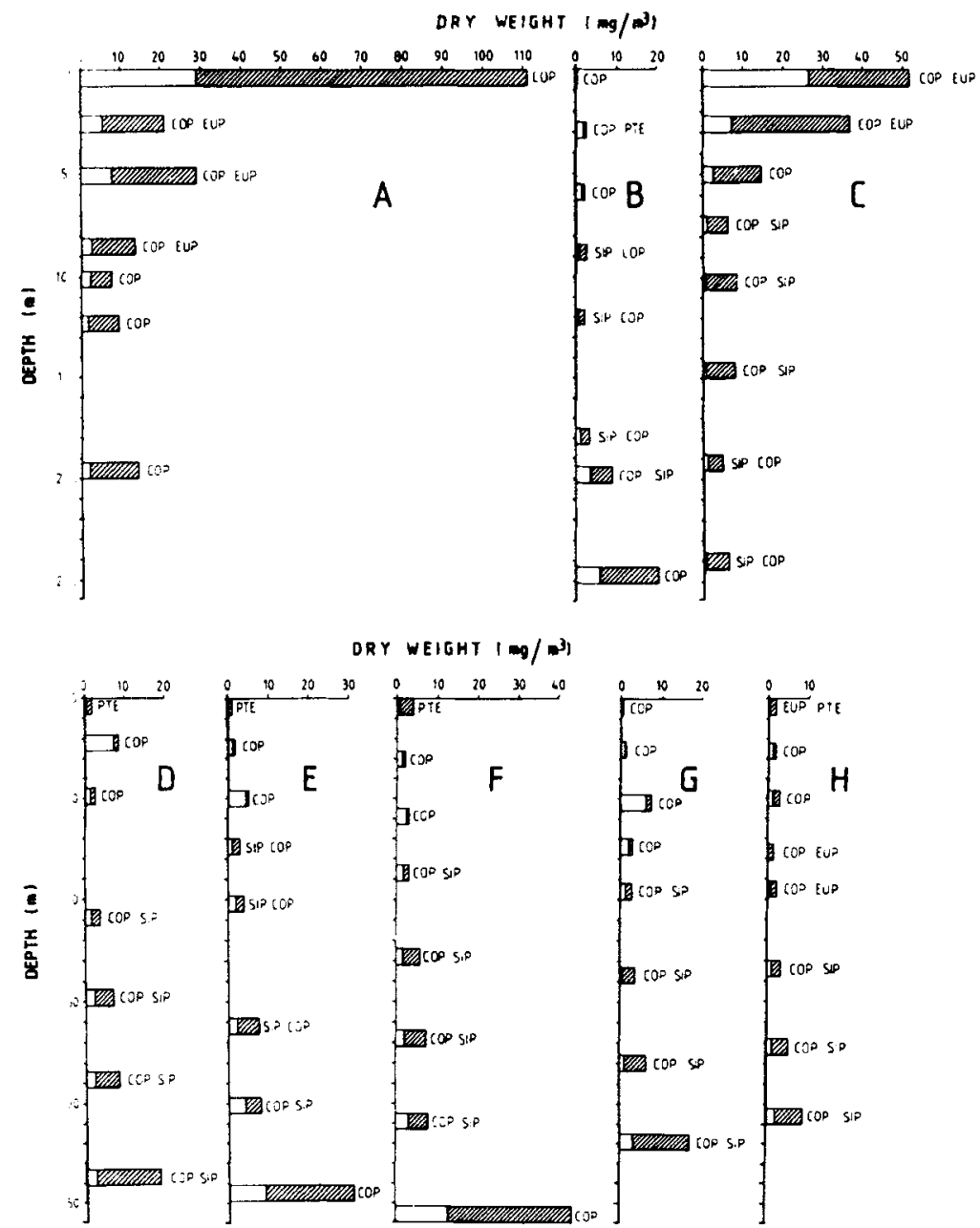

Fig. 5. Examples of MOCNESSbiomass (AFDW) profiles from stations in Polar Front Water. Open bars: $<1 \mathrm{~mm}$ size fraction; hatched bars: $>1 \mathrm{~mm}$ fraction. Dominating taxonomic groups: PTE = pteropods, $\mathrm{COP}=$ copepods, AMP = amphipods, CHA = chaetognaths. EUP = euphausiids. SIP = siphonophores. A. No capelin present. B. Low abundance of capelin (integrator values $<100$ ) C-H High abundance of capclin (integrator values $>100$ ). 
The zooplankton data has also been grouped into 3 categories of stations with no, low and high abundance of capelin, respectively (Table 4). The mean total biomass of MOCNESS samples was only about $1 / 3$ at the stations with high abundance of capelin compared to the stations without capelin. This difference was significant (MannWhitney U-test, $U=151, p<0.002)$ and reflected lower biomass in the size fraction $>1 \mathrm{~mm}$ (Table 4). The Juday samples showed the same trend, with lower total biomass and biomass in the $>1 \mathrm{~mm}$ size fraction at the stations with high abundance of capelin. The difference in total biomass was significant for the comparison between stations with high and low abundance of capelin $(U=254, p<0.05)$.
The capelin was distributed mainly in Polar Front and Arctic/Atlantic water masses (Fig. 3B, D). Sixteen out of the total of 30 MOCNESS stations were located in these water mass categories. Vertical profiles revealed low zooplankton biomass in the upper water layer at 5 out of 6 Polar Front stations where capelin abundance was high (Fig. 5 D-H). In contrast, the single Polar Front station without capelin had a high biomass of zooplankton (Fig. $5 \mathrm{~A}$ ). An exception to this pattern was Station 880 which had fairly high zooplankton biomass and high capelin abundance (Fig. 5C). This station, however, was located just inside the northern border of the capelin front at $76^{\circ} 40^{\prime} \mathrm{N}$ and $31^{\circ} \mathrm{E}$. Station 937 was located slightly to the northeast
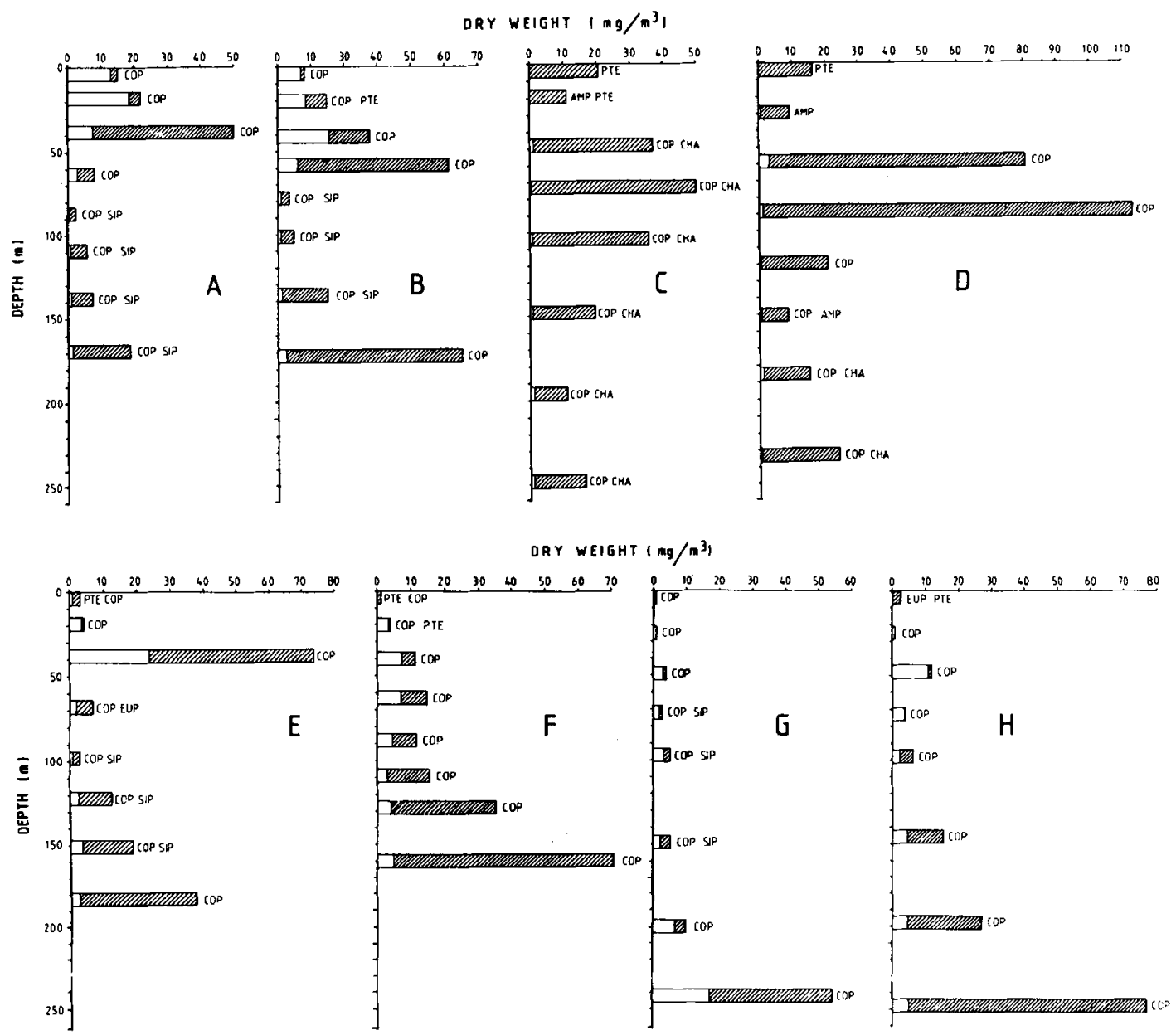

Fig. 6. MOCNESS biomass profiles from stations in Arctic/Atlantic Water: A-D. No capelin: E. Low capelin abundance: F-H: High capelin abundance. 
of station $880\left(76^{\circ} 45^{\prime} \mathrm{N}, 31^{\circ} 30^{\prime} \mathrm{E}\right)$ in an area with low abundance of capelin and had low biomass of zooplankton (Fig. 5B). Stations 885 and 932 were from the same geographical position taken about one week apart. It is noteworthy how little change there had been in the zooplankton biomass distribution (Fig. 5D, E).

The vertical profiles of zooplankton at the stations in the Arctic/Atlantic water mass revealed the same general pattern as the stations in Polar Front Water. The zooplankton biomass in the upper layer was considerably lower at the stations with high abundance of capelin (Fig. 6F-H) than at the stations with no capelin present (Fig. $6 \mathrm{~A}-$ D). The station with low abundance of capelin had intermediate level of zooplankton (Fig. 6E).

Vertical profiles of zooplankton biomass in other water mass categories are shown in Fig. 7. Two stations in "old" Atlantic Water and Atlantic Water with high abundance of capelin had very low zooplankton biomass in the upper water layer (Fig. 7D, E). The only station in Atlantic Water
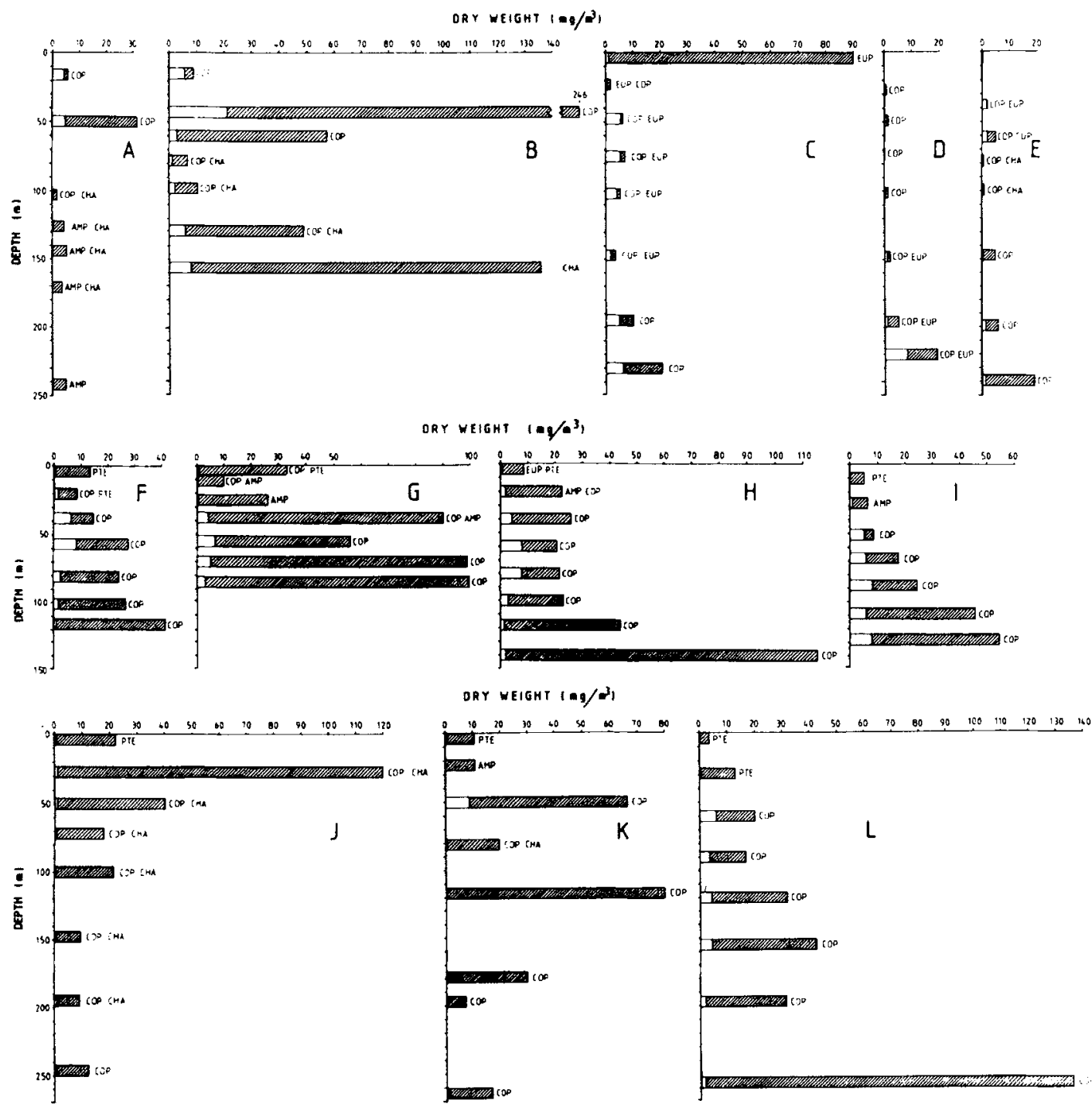

Fig. 7. MOCNESS biomass profiles from Atlantic Water (A. E), "old" Atlantic Water (B-D), and Arctic Water (F-L): A, F-L. No capelin; B-C. Low capelin abundance; D-E. High capelin abundance 
without capelin, located in the southwestern part of the Barents Sea, had somewhat higher biomass (Fig. 7A). Two stations in "old" Atlantic Water with low abundance of capelin showed fairly high zooplankton biomass but with different vertical distributions. Station 850 was located on the northern slope of Sentralbanken and had low biomass in the upper layer but high biomass from $40 \mathrm{~m}$ and deeper (Fig. 7B). Station 878 was located in the northwestern part of the capelin distribution and had high biomass (of krill) in the surface layer but low biomass below (Fig. 7C).

Capelin was not observed in the Arctic Water proper. The zooplankton biomass at the Arctic Water stations was generally high but with some variation in the vertical distribution (Fig. 7 F-L). Stations 814,841 and 867 along the eastern slope of Spitsbergenbanken and Stations 857 and 917 southeast of Storbanken (Fig. 1) showed a general increase in the zooplankton biomass with increasing depth (Fig. 7F-H, I, L) Stations 896 and 913 in the northern Barents Sea showed the highest biomass in the upper or intermediate water layers (Fig. 7J, K).

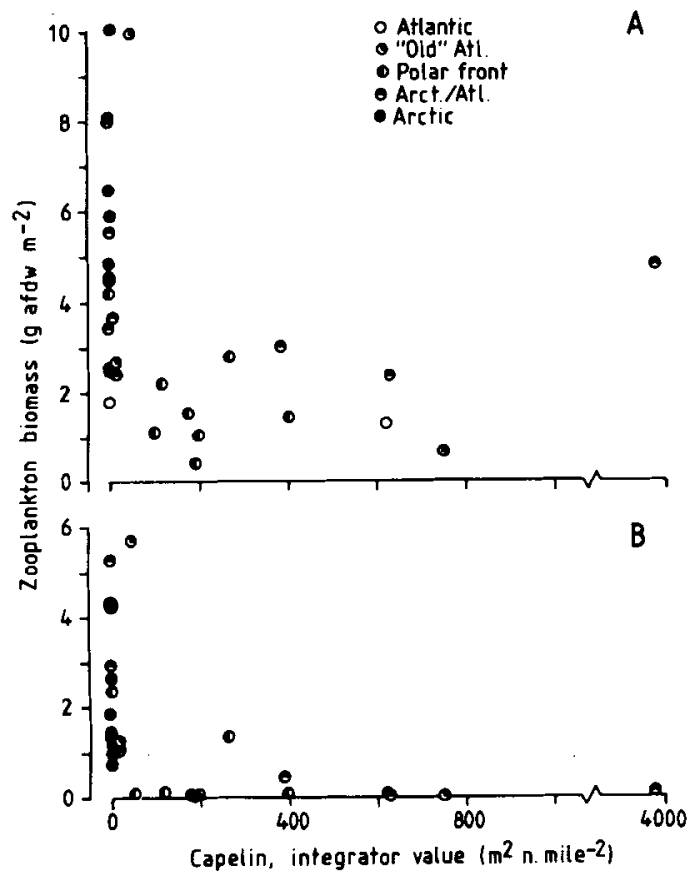

Fig. 8. Relationship between capelin abundance (integrator value) and zooplankton biomass from bottom to surface (A) and from above $100 \mathrm{~m}$ depth (B).
There was an inverse reationship between zooplankton biomass and capelin abundance for all MOCNESS stations (Fig. 8). This trend was most clearly shown for the zooplankton in the upper $100 \mathrm{~m}$, with very low zooplankton biomass at most stations where capelin was present (Fig. $8 \mathrm{~B})$.

\section{Zooplankton taxonomic composition}

The dominant groups of zooplankton, based on visual examination of the sample vials, have been indicated on Figs. 5-7. Copepods and to a lesser degree siphonophores dominated the Polar Front and Arctic/Atlantic stations with high abundance of capelin. Euphausids were dominant together with copepods at those Polar Front stations where the zooplankton biomass was high (Fig. 5A, C). Pteropods and amphipods were dominant in the surface layer at most of the stations with no capelin in the Arctic/Atlantic and Arctic water masses (Figs. 6B-D and 7F-L). Chaetognaths were also common in the intermediate and deeper layers at some of these stations (Figs. 6C, D and $7 \mathrm{~J}$ ) as well as at some stations in Atlantic Water or "old" Atlantic Water (Fig. 7A, B, E).

The zooplankton species composition has been analysed in four MOCNESS profiles. Stations 829 and 878 (Fig. 9) were from "old" Atlantic Water with high and low abundance of capelin, respectively. Stations 890 and 901 (Fig. 10) were from Arctic/Atlantic Water, located in an area with low abundance of capelin and north of the capelin front, respectively (Fig. 1). Station 829 had low abundance of all zooplankton species in the upper layer (Fig. 9), in agreement with the biomass profile (Fig. 7D). The dominant copepod was Calanus finmarchicus at both the "old" Atlantic stations. This species showed a clear pattern, with the younger stages (II and III) being dominant in the upper $100 \mathrm{~m}$ and the overwintering stage $\mathrm{V}$ found in the deepest layer (Fig. 9A, B). The abundance of the younger stages of $C$. finmarchicus was much higher at Stn. 878 than at Stn. 829. C. finmarchicus was also common at Stn. 890, Arctic/Atlantic Water, with stages IIIV present in high abundance in the upper $40 \mathrm{~m}$ (Fig. 10A). C. finmarchicus was rare at Stn. 901 further north, with stages $\mathrm{V}$ and adult females being present in low abundance (Fig. 10B).

Calanus glacialis was present at the "old" Atlantic Stations 829 and 878 , but with much lower abundance than $C$. finmarchicus. Stage IV 


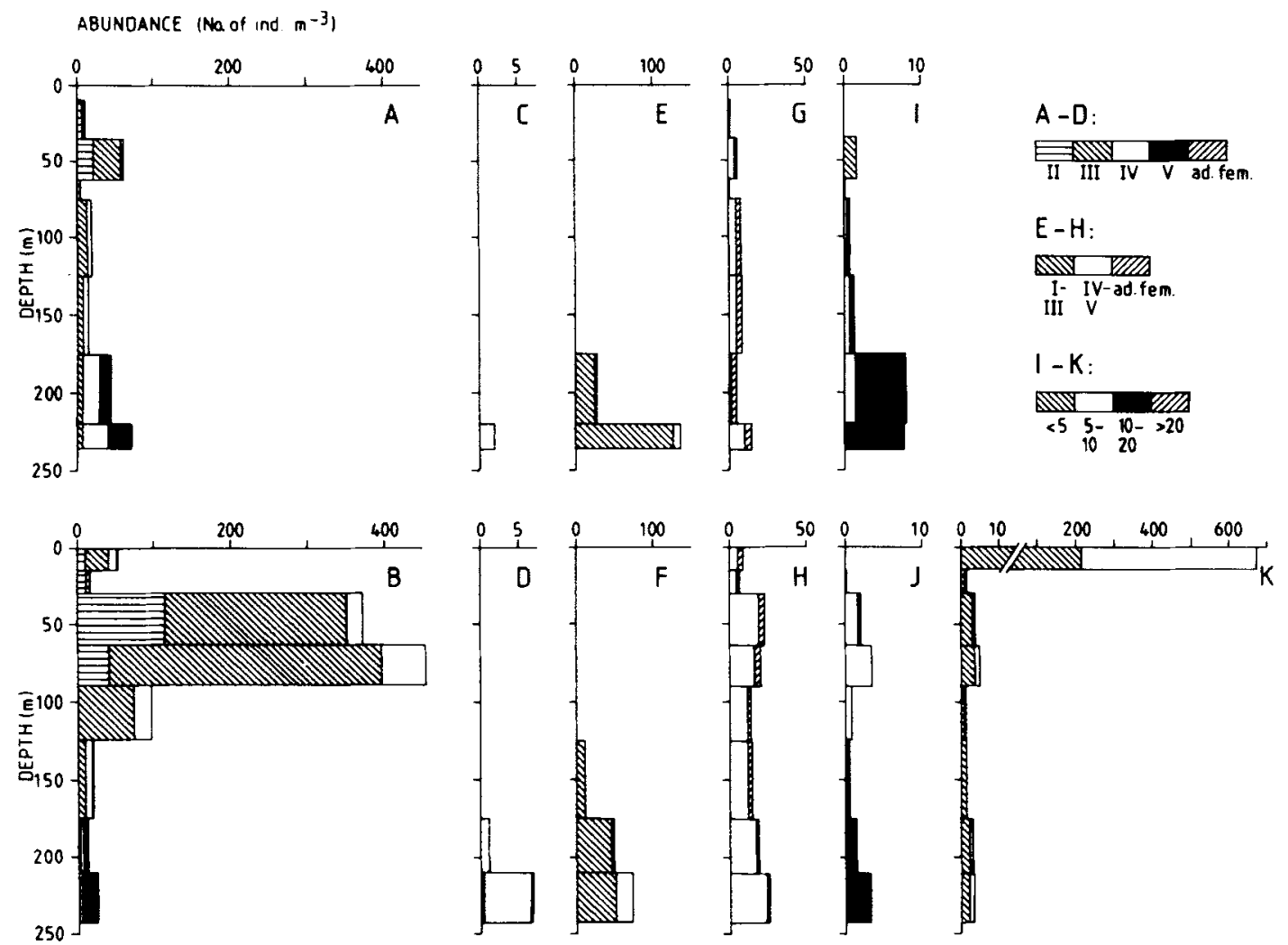

Fig. 9. Vertical profiles of dominating zooplankton species from Stations 829 (above) and 878 (below): A-B. Calanus finmarchicus; C-D. C. hyperboreus; E-F. Metridia longa: G-H. Pseudocalanus sp. : I-J. Chactognats; K. Euphausiids. Key to copepodite stages and length $(\mathrm{mm})$ groups at upper right.

was the dominant stage and was found mainly in the deepest layer. $C$. glacialis was abundant in the upper layer at the Arctic/Atlantic Station 890 where it contributed to the biomass peak at 20$40 \mathrm{~m}$ (Figs. 6E and 10C). Stages III and IV were dominant at this station, while being rare at Stn. 901 . Here stage $V$ dominated, being found mainly from 30 to $90 \mathrm{~m}$ (Fig. 10D).

Calanus hyperboreus occurred in fairly low abundance at all four stations, particularly Stn. 829. The population was comprised almost exclusively of stage IV copepodites at Stations 829 and 878 and was distributed in the deepest layers (Fig. 9C, D). Stage IV also dominated in the deepest layer at Stn. 890 but with some stage III and IV individuals present in the upper layer as well (Fig. $10 \mathrm{E}$ ). A similar bimodal vertical distribution was found at Stn. 901 where stage V dominated (Fig. 10F).

Metridia longa was distributed in the deeper part of the water column at all four stations. Young copepodites (stages I-III) dominated at the stations in "old" Atlantic Water, whereas older stages (IV-V) dominated at the stations in Arctic/Atlantic Water (Figs. 9E, F and 10G, H).

Pseudocalanus sp. was distributed fairly evenly throughout the water column. The abundance was low in the surface layer, with a maximum around $30-50 \mathrm{~m}$ at the stations in Arctic/Atlantic Water (Figs. 9G, $\mathrm{H}$ and 10I, J). Copepodite stages IV and V dominated at the "old" Atlantic stations and at Stn. 890, whereas adult females were dominant at Stn. 901.

Sagitta elegans was the dominant chaetognath. At the "old" Atlantic stations, the larger chaetognaths $(10-20 \mathrm{~mm})$ were distributed in the deeper layer whereas smaller individuals were most abundant higher in the water column (Fig. 9I, J). The abundance of chaetognaths was fairly low and dominated by small individuals (5- 
$10 \mathrm{~mm}$ ) at Stn. 890 in Arctic/Atlantic Water (Fig. $10 \mathrm{~K})$. The abundance was higher and contributed to the higher biomass at Stn. 901, with larger individuals found primarily between 30 and $60 \mathrm{~m}$ (Figs. 6C and 10L).

Hyperiid amphipods were found in low abundance at all stations. Individuals of Parathemisto libellula larger than $10 \mathrm{~mm}$ were found at the stations in Arctic/Atlantic Water with the highest abundance in the upper layer (Fig. 10M, N).

The dominant species of krill in the investigated area were Thysanoessa inermis and $T$. longicaudata (Dalpadado \& Skjoldal 1991). No krill was found at Stn. 829 where capelin was present. In contrast, a high abundance of furcilia larvae of krill (about $10^{3}$ individuals $\mathrm{m}^{-2}$ ) was found at $\mathrm{Stn}$. 878 with low abundance of capelin. The krill larvae were strongly concentrated in the surface layer and contributed to the high biomass in this layer (Figs. 7C and 9K). A few furcilia larvae were also found at Stations 890 and 901 in the Arctic/Atlantic Water, and larger individuals of $T$. inermis were found in low abundance at Stn. 890.

Pteropods contributed to the biomass in the surface layer at Stn. 901 (Fig. 6C). This was mainly due to large individuals of Limacina helicina (5-10 mm) and Clione limacina.

\section{Capelin feeding}

The amount of stomach content of capelin varied greatly within the investigated area (Table 5). The mean stomach fullness (expressed as percentage of body weight) was largest in the Arctic Water with 7.9 and $7.7 \%$ for small and large capelin (10-13.5 and $14-17.5 \mathrm{~cm}$ total length), respectively. The lowest stomach fullness was

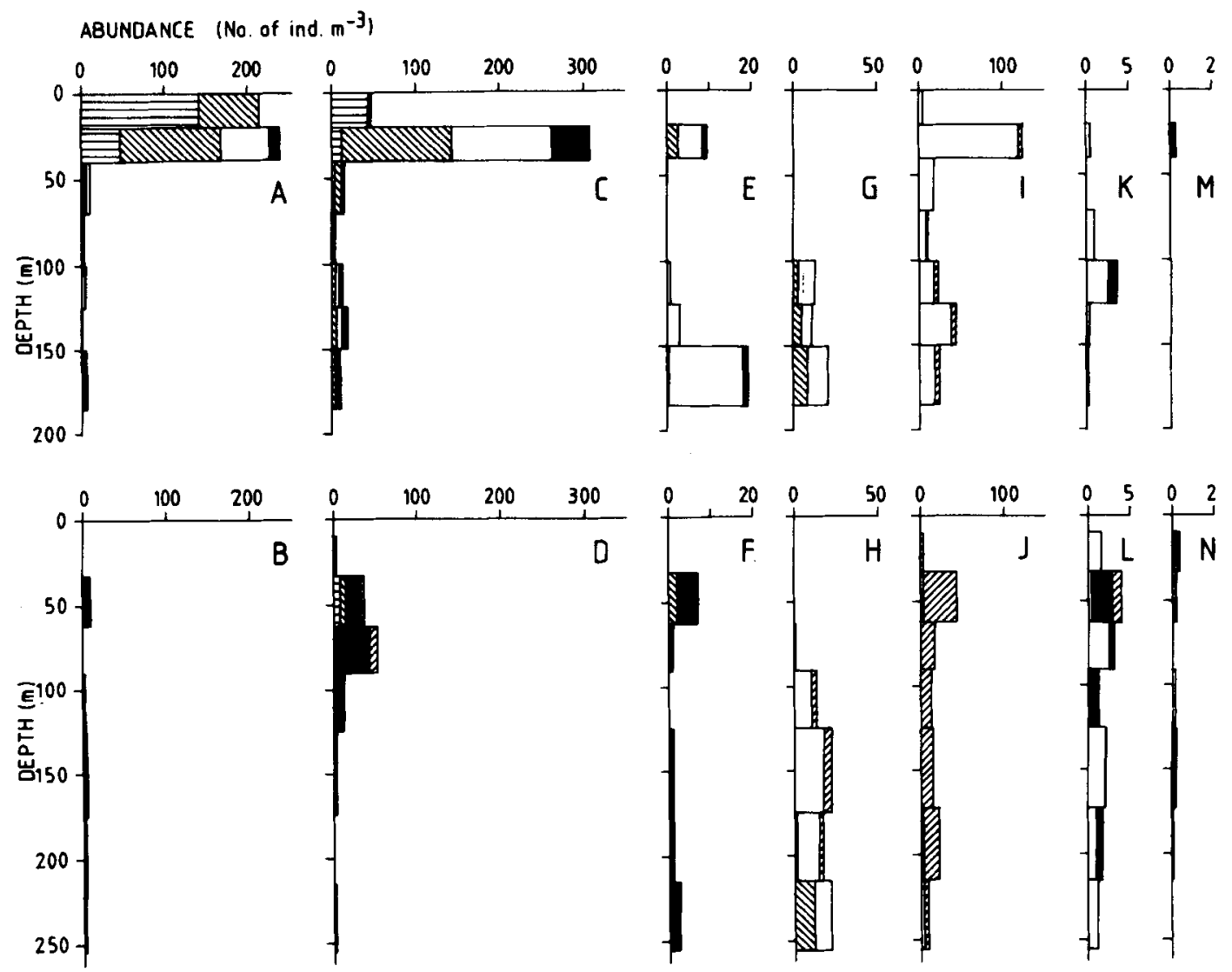

Fig. 10. Vertical profiles of zooplankton species from station 890 (above) and 901 (below): A-B. C. finmarchicus: C-D. C. glacialis; E-F. C. hyperboreus; G-H. M. longa; I-J. Pseudocalanus sp.: K-L. Chactognaths: M-N, Amphipoda. 
Table 5. Mean values and standard deviation of fish length. fish weight. weight of stomach content. and stomach fullness from different water types. $\mathrm{N}=$ numbers of individuals.

\begin{tabular}{|c|c|c|c|c|c|c|c|}
\hline Water type & $\mathbf{N}$ & $\begin{array}{l}\text { Length } \\
\text { group } \\
(\mathrm{cm})\end{array}$ & & $\begin{array}{l}\text { Fish } \\
\text { length } \\
(\mathrm{cm})\end{array}$ & $\begin{array}{l}\text { Fish } \\
\text { weight } \\
\text { (g) }\end{array}$ & $\begin{array}{l}\text { Stomach } \\
\text { content } \\
(\mathrm{mg})\end{array}$ & $\begin{array}{l}\text { Stomach } \\
\text { fullness } \\
(\%)\end{array}$ \\
\hline \multirow[t]{4}{*}{ Arctic } & 12 & $10-13.5$ & Mean & 13.21 & 10.97 & 812 & 7.91 \\
\hline & & & $\mathrm{SD}$ & 0.50 & 1.25 & 486 & 4.82 \\
\hline & 40 & $14-17.5$ & Mean & 15.00 & 17.18 & 1231 & 7.67 \\
\hline & & & SD & 0.81 & 3.65 & 795 & 4.25 \\
\hline \multirow[t]{4}{*}{ Arct./Atl. } & 81 & $10-13.5$ & Mean & 12.22 & 7.77 & 145 & 1.83 \\
\hline & & & $\mathrm{SD}$ & 0.68 & 1.46 & 123 & 1.39 \\
\hline & 2 & $14-17.5$ & Mean & 15.75 & 18.13 & 28 & 0.16 \\
\hline & & & $\mathrm{SD}$ & 0.35 & 1.12 & 40 & 0.23 \\
\hline \multirow[t]{4}{*}{ Old Atlantic } & 134 & $10-13.5$ & Mean & 12.06 & 6.76 & 64 & 0.96 \\
\hline & & & $\mathrm{SD}$ & 1.02 & 2.01 & 79 & 1.14 \\
\hline & 63 & $14-17.5$ & Mean & 14.61 & 14.28 & 406 & 2.73 \\
\hline & & & $\mathrm{SD}$ & 0.58 & 2.87 & 431 & 2.76 \\
\hline \multirow[t]{4}{*}{ Polar Front } & 213 & $10-13.5$ & Mean & 12.05 & 7.63 & 228 & 2.88 \\
\hline & & & $\mathrm{SD}$ & 1.06 & 2.47 & 279 & 2.78 \\
\hline & 137 & $14-17.5$ & Mean & 13.26 & 11.09 & 374 & 3.35 \\
\hline & & & $\mathrm{SD}$ & 1.69 & 4.65 & 490 & 3.59 \\
\hline
\end{tabular}

found in Old Atlantic Water (1.0 and 2.7\%) and Arctic Water $(1.8$ and $0.2 \%)$.

The stomach fullness values at 14 trawl stations were compared to the zooplankton biomass obtained with Juday net or MOCNESS at the nearest station (Fig. 1). No significant simple correlations were found. The MOCNESS data showed positive correlations, with correlation coefficients of 0.31 and 0.52 for the total zooplankton biomass in the whole water column and the upper $100 \mathrm{~m}$, respectively. The MOC-

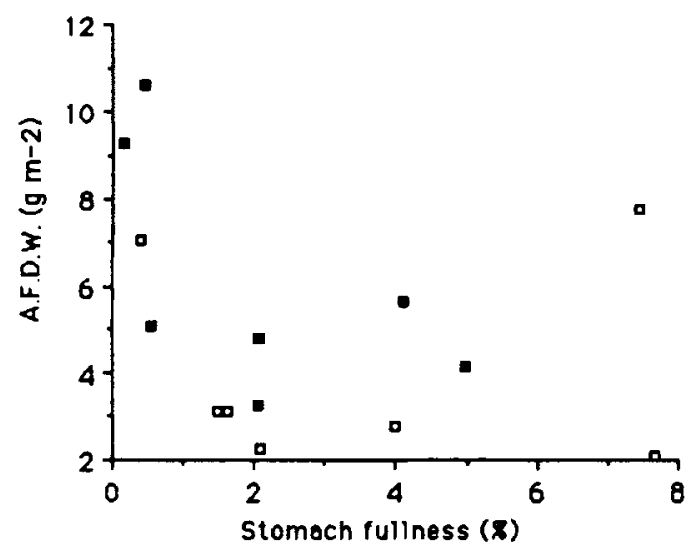

Fig. 11. Relationship between stomach fullness of capelin and total zooplankton biomass from Juday-net samples. Open symbols $=$ trawl catches from above $100 \mathrm{~m}$ depth. Solid symbols $=$ catches from deeper than $100 \mathrm{~m}$.
NESS data was limited, however, to 8 data points. The Juday data set was larger and included 14 stations for the comparison. There was large scatter in the data points with no clear relationship between Juday biomass and capelin stomach fullness $(r=-0.30$ and -0.17 for total biomass and $>1 \mathrm{~mm}$ size fraction, respectively; Fig. 11). The influence of factors other than zooplankton biomass was tested with multiple regression analysis. A significant overall regression was found, with effects of capelin length and depth of trawling being significant or close to significant (Table 6).

One reason zooplankton biomass was so poorly related to capelin stomach content (Fig. 11, Table 6) was probably that the Juday data lacked vertical resolution. The three data points in the upper left corner of Fig. 11, showing low stomach fullness and high zooplankton biomass, were all from

Table 6. Results of a multiple regression analysis between capelin stomach fullness as dependant variable and time and depth of sampling. mean capelin length and total zooplankton biomass obtained with Juday net as independant variables.

\begin{tabular}{lrl}
\hline Variable & \multicolumn{1}{c}{} & Level of sign. (p) \\
\hline Time & 0.03 & 0.976 \\
Depth & -2.17 & 0.058 \\
Length & 3.23 & 0.010 \\
Zoopl. biomass & -1.26 & 0.238 \\
Multiple $\mathrm{R}=0.813$ & & 0.030 \\
\hline
\end{tabular}


Table 7. Mean weight $(\mathrm{mg})$ of prey categories in capelin stomachs from four trawl stations.

\begin{tabular}{lcrrr}
\hline & St. 373 & St. 378 & St. 384 & St. 385 \\
\hline Calanoida & 1.05 & 51.19 & 303.72 & 70.98 \\
Cyclopoida & 0.002 & & 0.10 & \\
Ostracoda & 0.003 & & 0.53 & \\
Cladocera & 0.003 & & & \\
Amphipoda & 1.52 & & & \\
Euphausiacea & 29.12 & 3.75 & 1.26 & 642.58 \\
Larvacea & 0.61 & 43.70 & & \\
Gastropoda & & 0.04 & & \\
Decapoda & & & 0.15 & \\
\hline
\end{tabular}

areas with high abundance of capelin. Two of these stations (829 and 852) were from "old" Atlantic Water, while the third station (846) was from the Polar Front area (Fig. 1). The MOCNESS profile taken at Station 829 revealed very low zooplankton biomass in the upper layer (Figs $7 \mathrm{D}$ and $9 \mathrm{~A}-\mathrm{I}$ ). It is possible that the zooplankton biomass was low in the upper layer also at the other two stations.

The composition of prey in the capelin stomachs varied considerably between stations (Table 7). Trawl Station 373 was from "old" Atlantic Water or Polar Front Water at the eastern slope of Spitsbergenbanken. Stations 378, 384, and 385 were situated in "old" Atlantic Water, Polar Front Water and Arctic Water, respectively, between Hopen and Sentralbanken. All stations were from areas where echo-integration values exceeded 100 . Krill and copepods were the two main prey groups found in the stomachs. The copepods were mainly Calanus finmarchicus and $C$. glacialis. Individuals of $\mathrm{Cal}$ anus with cephalothorax length from 1.5 to $2.5 \mathrm{~mm}$ strongly dominated in terms of weight at two stations $(378,384)$, while krill, mostly Thysanoessa inermis, was the most important food item at the other two stations. Amphipods were only observed as prey on Station 373 and were of minor importance. The number and weight of Larvacea (Oikopleura sp.) are more uncertain, but this group was a relatively important food item at Station 378.

\section{Discussion}

Our results give strong indications for a grazing impact by capelin on zooplankton in the Barents Sea. Thus the zooplankton biomass was sig- nificantly lower in the area with high abundance of capelin than in the area with no capelin. This effect was due to the large size fraction of zooplankton and seen most clearly in the data obtained with MOCNESS (Table 4, Figs. 3 and 4). The effect was furthermore seen most clearly for zooplankton in the upper part of the water column (Figs. 5-7). These trends are as expected for a visual predator like capelin which select larger zooplankton as prey (Hassel 1984).

The evidence for grazing impact is not absolutely conclusive, however, due to the fact that the capelin front more or less coincided with the physical Polar Front (Fig. 3). This made our study design less suitable for statistically proving an inverse relationship between capelin and zooplankton abundance. A further element in our design was to revisit the capelin front area after about one week to seek evidence for any decrease in zooplankton abundance in relation to the migrating capelin front. Observations in the summers of 1979 and 1980 had indicated a migration speed of 5-10 $\mathrm{km} \mathrm{d}^{-1}$ (Gjøsæter et al. 1983). Unfortunately, there was little change in the capelin distribution between the first and second survey in the present case (Fig. 3C). The capelin appeared to be reluctant to cross into the cold Arctic Water on Storbanken. Results from the annual capelin stock assessment cruise in September showed that some capelin had migrated onto Storbanken, but the densest concentrations were found west of Storbanken (Anon 1985).

The timing of our study was unfortunate also with respect to the development of the capelin stock which decreased drastically from 1984 to 1986 (Hamre 1990). The capelin stock was reduced to about 1 million tonne in the autumn 1985 , compared to a stock size of 4-6 million tonnes in the late 1970 s and early $1980 \mathrm{~s}$. This made the grazing impact by capelin correspondingly lower.

Light is an important factor controlling predation by visually feeding predators (Giske et al. 1990). This implies that predation by capelin is likely to be more intensive in the upper water layer due to better light conditions for hunting mobile prey such as copepods, krill and amphipods. This would explain the strong negative relationships found between abundance of capelin on one hand and zooplankton biomass in the upper part of the water column on the other (Figs. 5-8 and 11). Previous investigations have revealed the highest stomach content of capelin during 
daytime, with lower values during the night (Panasenko 1981, 1984; Hassel \& Gjøsæter unpubl.).

The major food items of capelin are calanoid copepods, krill, and, to a lesser degree, amphipods. Selectivity by size has been demonstrated, with small capelin feeding on copepods, and larger capelin feeding on krill and amphipods, if they are available (Panasenko 1984; Hassel unpubl. results). Size selectivity is the likely explanation why evidence for grazing impact by capelin was found only for the size fraction $>1 \mathrm{~mm}$ (Table 4). This size fraction would contain krill and amphipods, as well as chaetognaths and large calanoid copepods such as older stages of Calanus hyperboreus and $C$. glacialis. The $<1 \mathrm{~mm}$ size fraction would typically be dominated by small copepods and younger stages of the Calanus species.

The $>1 \mathrm{~mm}$ size fraction made up most of the zooplankton biomass (Fig. 4). This reflected partly the dominance of large copepods (Figs. 57, 9 and 10). The MOCNESS sampler and Juday net produced surprisingly similar estimates of biomass, considering the differences in their size and mode of operation. The MOCNESS tended to give somewhat higher values than the Juday net for the largest size fraction and smaller values for the smallest size fraction (Tables 2 and 4 ). This can be explained by more efficient sampling by MOCNESS of large and mobile organisms, and less efficient sampling of small copepods due to the larger mesh size ( 333 vs. $180 \mu \mathrm{m}$ ).

The vertical distribution of zooplankton will influence the feeding activity of capelin, but will itself be modified by capelin predation being highest in the upper layer. Herbivorous zooplankton such as the Calanus species have a seasonal downward migration in late summer or autumn. The deep distributions of Metridia longa, Calanus hyperboreus and stages IV and V of C. finmarchicus no doubt reflected this seasonal vertical migration, whereas young copepodite stages of C. finmarchicus and C. glacialis were still present in the upper layer (Figs. 9 and 10). Selective grazing by capelin on the older stages would, however, contribute to the observed patterns of vertical distributions.

Investigations during two 24-hour stations in the same area in August 1984 revealed increasing stomach content of capelin during daytime, both for fish caught in the upper $50 \mathrm{~m}$ and deeper than $120 \mathrm{~m}$ (Hassel \& Gjøsæter unpubl.). A common pattern is that small capelin are found high in the water column while larger capelin are found deeper down (H. Gjøsæter pers. comm.; Hassel et al. 1984). This may be a reflection of the distribution of zooplankton, with small copepods in the upper part and large copepods in the deeper part of the water column (Figs. 5, 6, 9 and 10). Panasenko $(1981,1984)$ reported that capelin performed diurnal vertical migration in late August. The stomach fullness was maximum during the day when capelin was feeding on copepods, krill and amphipods in the deeper layer. During night, capelin were distributed scattered over the water column while the stomach content decreased.

The relationship between capelin and zooplankton is complex and dynamic. In addition to light, vertical distribution, size and species composition of zooplankton, the horizontal migration of capelin needs also to be taken into account. The inverse relationship found between zooplankton biomass in the upper $100 \mathrm{~m}$ and capelin abundance (Fig. 8B) suggests a very rapid depletion of zooplankton by capelin. In the case studied here, the capelin front had a density of about 1000 echo integrator units (Fig. 3D). Using routine conversion factors to numbers and weight (Dommasnes \& Røttingen 1984), this is equivalent to a capelin biomass of about $15 \mathrm{~g}$ dry weight $\mathrm{m}^{-2}$. This is about three times the average biomass of zooplankton in areas without capelin (Table 4). Assuming a turnover of 24 hours and a maximum stomach content of $10 \%$, capelin could graze the available zooplankton biomass in 3-4 days.

Total depletion of zooplankton is not likely to occur. The picture which emerges, however, is one where a migrating capelin front quickly grazes down the larger zooplankton organisms available. Left behind is a depleted upper layer, dominated by small and less conspicuous forms, with most of the remaining zooplankton found in the deeper part of the water column.

The lack of correlation between capelin stomach fullness and zooplankton biomass obtained with Juday net (Fig. 11, Table 6) illustrates the problem of establishing relationships between available food and stomach fullness. Our results show that it is important to consider the vertical distribution of the zooplankton as well as the predator. These aspects are essential when modelling multispecies relations where food consumption and growth of capelin is involved (Tjelmeland unpubl.).

The northwards feeding migration of capelin can be viewed as an adaption to exploit the plank- 
ton production associated with the receding ice edge (Sakshaug \& Skjoldal 1989). The necessity to migrating would depend on the biomass of available zooplankton as well as on the size of the capelin stock. The annual production of capelin is about equal to or slightly higher than the standing stock (Hamre 1990). This is in good agreement with the general relationship reported by Banse \& Mosher (1980) for size-dependency of annual $\mathrm{P} / \mathrm{B}$ ratios, which predicts a value of about 1.2 for a fish of the size of capelin. A stock of about 5 million tonnes as during the late 1970s (Hamre 1990 ), would have a food requirement of about 30 million tonnes assuming $20 \%$ growth efficiency.

The annual primary production in the Barents Sea is about $70 \mathrm{~g} \mathrm{C} \mathrm{m}^{-2}$ (Rey et al. 1987a). Assuming $20 \%$ ecological efficiency from phytoplankton to zooplankton, this implies that the secondary production is $14 \mathrm{~g} \mathrm{C} \mathrm{m}^{-2}$, or about $150 \mathrm{~g}$ in terms of wet weight (Båmstedt 1974; Ikeda 1974). A food consumption of 30 million tonnes would require all the secondary production from an area of 0.2 million $\mathrm{km}^{2}$ or $15 \%$ of the total area of the Barents Sea. This is obviously a minimum estimate as it assumes that all the secondary production is of a form that can be consumed by capelin. This is not the case. A large part of the spring bloom can be left ungrazed by mesozooplankton, resulting in massive sedimentation (Skjoldal \& Rey 1989; Wassmann 1989; Wassmann et al. 1990). A portion of the primary production will also go through the microbial loop of the food web. Among the zooplankton produced that are suitable as prey for capelin, some will be consumed by other carnivores such as polar cod, herring, juvenile fish, chaetognaths, ctenophores and medusae. There is large variability in the conversion efficiency from spring bloom to zooplankton among different areas and years (Skjoldal \& Rey 1989). It is a fair "guestimate" however, that on the average only about $1 / 4$ of the secondary production will be suitable and available as prey for capelin. In that case a stock of 5 million tonnes of capelin would need to graze more than half the area of the Barents Sea to sustain its production.

Acknowledgements. - This work is a contribution from the Pro Mare programme and was supported by the Norwegian Fisheries Research Council (NFFR).

\section{References}

Anon 1985: Report on the joint Norwegian/USSR acoustic survey of capelin and herring in the Barents Sea in September-October 1985. Institute of Marine Research. Bergen. $19 \mathrm{pp}$.

Båmstedt, U. 1974: Biochemical studies on the deep water pelagic community of Korsfjorden, Western Norway. Methodology and sample design. Sarsia 56, 71-86.

Banse, K. \& Mosher, S. 1980: Adult body mass and annual production/biomass relationships of field populations. Ecol. Monogr. 50, 355-379.

Dalpadado, P. \& Skjoldal, H. R. 1991: Distribution and life history of krill from the Barents Sea. Pp. 443-459 in Sakshaug, E., Hopkins, C. C. E. \& Øritsland N. A. (cds.): Proceedings of the Pro Mare Symposium on Polar Marine Ecology, Trondheim. 12-16 May 1990. Polar Research 10 (2).

Dommasnes, A. \& Røttingen, 1. 1984: Acoustic stock measurement of the Barents Sea capelin 1972-1984. A review. Pp. 45-108 in Gjøsater, H. (ed): The proceedings of the SovietNorwegian symposium on the Barents Sea capelin. Institute of Marine Research. Bergen, Norway, 1984.

Forberg, K. \& Tjelmeland, S. 1985: Maturity studies of Barents Sea capelin. Variations in length and maturity for female capelin. Pp. 213-222 in Gjøsæter, H. (ed): The proceedings of the Soviet-Norwegian symposium on the Barents Sea capelin. Institute of Marine Research. Bergen, Norway, 1984.

Giske, J., Aksnes, D. L., Baliño, B. M., Kaartvedt, S., Lie, U., Nordeide. J. T., Salvanes, A. G. V., Wakili, S. M. \& Aadnesen, A. 1990: Vertical distribution and trophic interactions of zooplankton and fish in Masfjorden, Norway. Sarsia $75.65-81$.

Gjøsæter, H., Hassel, A.. Loeng, H. \& Rey, F. 1983: Marinøkologiske undersøkelser nar iskanten i Barentshavet somrene 1979-1982. Sluttrapport for prosjektet "Lodda på sommerbeite". FO 8309. Havforskningsinstituttet i Bergen, 28 April 1983, 1-59.

Hamre. J. 1990: Biodiversity and exploitation of the main fish stocks in the Norwegian-Barents Sea ecosystem. Contribution to an international symposium on our common natural heritage, Bergen, Norway. May 2-6 1990. 26 pp.

Hassel. A. 1984: Ouantitative and qualitative aspects of capelin feeding in relation to zooplankton sources in the Barents Sea in May and August 1981. Contribution to the joint Soviet/ Norwegian symposium on the Barents Sea capelin - Norway A ugust 1984, 1-14.

Hassel, A., Loeng, H., Rey, F. \& Solberg, T. 1984: Resultater fra tokt med F/F "G. O. Sars" i Barentshavet 4.-19.8.1984. Havforskningsinstituttet, Rapport FO 8410, 1-32.

Hassel, A. 1986: Seasonal changes in zooplankton composition in the Barents Sea, with special attention to Calanus spp. (Copepoda). J. Plankton Res. 8, 329-339.

Ikeda, T. 1974: Nutritional ecology of marine zooplankton. Mem. Fac. Fish., Hokkaido Univ. 22, 1-97.

Loeng. H., Hassel, A., Rey, F. \& Skjoldal, H.R. 1986: Physical and biological oceanography and capelin front study. Pp. 560 in Loeng, H. (ed): Ecological investigations in the Barents Sea, August 1985. Report from Pro Mare-cruise No. 5. Report No. FO 8605. Havforskningsinstituttet, Bergen, 31.01.1986.

Loeng, H. \& Hassel, A. 1986: Loddas næringsforhold ved iskanten. Sluttrapport nr. NFFR 701.106. Rapport 8606. Havforskningsinstituttet, $6 / 6$ 1986, 1-15.

Loeng, H. 1989: Ecological features of the Barents Sea. Pp. 327-365 in Rey, L. and Alexander. V. (eds.): Proc. 6th Conf. Comité Arctique Internat. 13-15 May 1985. E. J. Brill, Leiden.

Loeng, H. 1991: Features of the physical oceanographic conditions of the Barents Sea. Pp. 5-18 in Sakshaug. E., Hopkins, C. C. E. \& Øritsland, N. A. (eds.): Proceedings of the Pro 
Mare Symposium on Polar Marine Ecology. Trondheim. 1216 May 1990. Polar Research 10 (1).

Ozhigin. V. K. \& Ushakov. N. G. 1984: The effect of the thermal conditions of the sea and atmospheric circulation on the distribution of the Barents Sea capelin fecding arcas. Pp.149-156 in Gjøsæter H (cd): The proceedings of the SovietNorwegian symposium on the Barents Sea capelin. Institute of Marine Research. Bergen. Norway, 1984.

Panasenko. L. D. 1981: Diurnal rhythms and rations of capelin feeding in the Barents Sea. ICES C.M. $1981 / H: 26,1-14$.

Panasenko. L. D. 1984: Feeding of the Barents Sea capelin. ICES C.M. 1984/H:6 Pel. Fish Comm., 1-16.

Rey, F. \& Loeng, H. 1985: The influence of ice and hydrographic conditions on the development of phytoplankton in the Barents Sea. Pp. $49-63$ in Gray. J. S. and Christiansen. M. E. (eds.): Marine biology of polar regions and effects of stress on marine organisms. Proccedings of the 18th European Marine Biology Symposium. Oslo. Norway. 14-20 August 1983. J. Wiley and Sons. Chichester.

Rey, F.. Skjoldal, H. R. \& Slagstad. D. 1987a: Primary production in relation to climatic changes in the Barents Sea. Pp. 1-46 in Loeng. H. (ed): The effect of oceanographic conditions on distriburion and population dynamics of commercial fish stocks in the Barents Sea. Proc. 3rd SovietNorwegian Symp. . Murmansk, 26-28 May 1986. Inst. Mar. Res.. Bergen.

Rey, F., Skjoldal. H. R. \& Hassel. A. 1987b: Seasonal development of plankton in the Barents Sea: A conceptual model. ICES symposium of marine sciences of arctic and subarctic regions. Report 57. Santander, Spain. $36 \mathrm{pp}$

Sakshaug. E. \& Skjoldal, H. R. 1989: Life at the ice edge. Ambio 18. 60-67.

Skjoldal, H. R.. Hassel. A.. Rey. F. \& Loeng. H. 1987. Spring phytoplankton development and zooplankton reproduction in the central Barents Sea in the period 1979-1984. Pp. 5989 in Loeng. H. (ed): The effect of oceanographic conditions on distribution and population dynamics of commercial fish stocks in the Barents Sea. Proc. 3rd Soviet-Norwegian Symp.. Murmansk, 26-28 May 1986. Inst. Mar. Res., Bergen.

Skjoldal, H. R. \& Rey. F. 1989: Pelagic production and variability of the Barents Sea ecosystem. Pp. 241-286 in Sherman. K. and Alexander, L. M. (eds.): Biomass yields and geography of large marine ecosystems. AAAS Selected Symposium 111. Westview Press.

Tande, K. S., Hassel, A. \& Slagstad. D. 1985: Gonad maturation and possible life cycle strategies in Calanus finmarchicus and Calanus glacialis in the northwestern part of the Barents Sea. Pp. 141-155 in Gray, J. S. and Christiansen. M. E. (eds.): Marine biology of polar regions and effects of stress on marine organisms. Proceedings of the 18th European Marine Biology Symposium. Oslo, Norway, 14-20 August 1983. J. Wiley and Sons, Chichester.

Vinje. T. 1983: Sea ice conditions in 1982. Norsk Polarinst Árbok 1982. Oslo. Norway, 49-53.

Wassmann. P. 1989: Sedimentation of organic matter and silicate from the euphotic zone of the Barents Sea. Rapp. P.-v. Reü. Cons. Int. Explor. Mer 188, 108-114.

Wassmann. P., Vernet. M., Mitchell, B. G. \& Rey, F. 1990: Mass sedimentation of Phaeocystis pouchetii the Barents Sca. Mar. Ecol. Prog. Ser. 66, 183-195.

Wiebe. P. H. . Burt, K. H. . Boyd, S. H. \& Morton, A. W. 1976: A Multiple opening/closing net and environmental sensing system for sampling zooplankton. J. Mar. Res. 34, 313-326. Wiebe. P. H. . Morton. A. W., Bradley, A. M. Backus, R. H., Craddock, J. E., Barber, V., Cowles, T. J. \& Flierl, G. R. 1985: New developments in the MOCNESS, an apparatus for sampling zooplankton and micronecton. Mar. Biol. 87, 313323. 